\title{
Impact of Caspian Sea Drying on Indian Monsoon Precipitation and Temperature as Simulated by RegCM4 Model
}

\section{Abhishek Lodh ${ }^{1,2 *}$}

${ }^{1}$ Indian Institute of Technology Delhi, Centre for Atmospheric Sciences, Hauz Khas, New Delhi 110016, India

${ }^{2}$ National Centre for Medium Range Weather Forecasting (NCMRWF) Earth System Science Organisation, Ministry of Earth Sciences, A-50, Sector-62, NOIDA- 201 309, India

\begin{abstract}
This study using a regional climate model, ICTP-RegCM4.0 simulations examines the impact of drying and shrinking of Caspian Sea on Indian summer and winter monsoon, particularly on precipitation over northern plains of India due to Western disturbances. Shrinking of Caspian Sea is a man-made catastrophe with serious environmental implications. To perform the sensitivity experiment the original landuse map in the model is altered where the "Caspian Sea" in Central Asia is changed to "semi-desert" in place of "inland water" type of vegetation. The model is forced with NNRP2 boundary conditions for year 2009, 2010. Analysis of sensitivity experiment output w.r.t baseline experiment says that rainfall over Northern India decreases (significant at $5 \%$ level), during the months of winter season (months of October to March) primarily from Western disturbances originating from Central Asia and Caspian Sea region. Also, it is found that minimum (maximum) temperature decreases (increases) particularly over Indian region during October to March and June to September. During June to September (for year 2009, 2010) from model simulations results it is found that over Central Asia (India) air temperature extending upto $700 \mathrm{hPa}$ increases (decreases).
\end{abstract}

Keywords: Regional climate model; Caspian sea; Precipitation; Western disturbances; Temperature

\section{Introduction}

Previous studies pertaining to Central Asia fails to draw a clear boundary between local and regional responses to global climate change and the trends caused by local land use changes, such as massive irrigation activities by constructing dams over the rivers feeding the Caspian Sea and the consequent desertification processes [1]. Though shrinking of the Aral Sea and Caspian Sea are considered as "Planet Earth's worst environmental disaster", hence in this research work it is planned to examine the impact of shrinking and drying of Caspian Sea on Indian monsoon circulation and precipitation. In the past few decades there is significant decrease in sea level of Caspian Sea attributed to human induced activities as threatened by pollution and climate change (http://www.naturalhistorymag.com/features/112161/ fate-of-the-caspian-sea).

There are various factors, which determine the climate of India. India is divided by the Tropic of Cancer, north of it lies in sub-tropical and temperate zone and the part lying south lies in the tropical zone. Westerly jet streams or winds along the altitude of $9-13 \mathrm{~km}(\sim$ $300 \mathrm{hPa}-150 \mathrm{hPa}$ ) flows from west to east through West and Central Asia. This westerly jet stream also blow across latitudes north of the Himalayas and reaches the Tibetan highlands. There are also shallow cyclonic depressions or western disturbances originating from Mediterranean Sea which travel eastwards across West Asia, Caspian Sea finally reaching Indian subcontinent, impacting weather of north India, northwestern India and Pakistan during the winter months (November, December, January, February and March). The westerly disturbances get moisture content from the Caspian Sea. Chaudhari et al. (2008) [2] while studying 2009 and 1994 Indian monsoons finds the cyclonic anomalous circulations develop over Caspian Sea near Central Asia during 2002 severe drought monsoon year whereas anticyclonic anomalous circulation develop during 1994 rain year. Rajeevan (1993) [3] found that anomalous cyclonic circulations with cold temperature over Caspian Sea develop during pre-monsoon season of Indian drought years, which persists during later monsoon season. Study by Rajeevan 1993 [3], strengthened the findings of Krishnamurthi et al. (1989) [4]. These cold cyclonic anomalies affect Indian summer monsoon by delaying the summer heating of the landmass [3]. Hence, the role of drying Caspian Sea in steering the westerly winds or disturbances towards India is addressed in this study in the context of climate change.

In this paper, the "methodology" of study is followed by "Result and Discussions" and then the "Conclusions" of the study.

\section{Methodology}

\section{Dynamical sownscaling approach}

The RegCM4.0 (regional climate model version 4.0) [5,6] coupled with BATS (Biosphere-Atmosphere Transfer Scheme) land surface scheme is used in this present study to test the objective. Parameterization schemes employed are same as reported in earlier studies [7-10] as Indian monsoon atmospheric circulations and regions of precipitation maxima are best simulated with these combination of parameterization schemes. The baseline landuse map file in the RegCM4.0 model is modified to represent the land use change map for the sensitivity experiment. The model is run at $90 \mathrm{~km}$ resolution for sensitivity study over the Cordex South-Asia domain $\left(12^{\circ} \mathrm{E}\right.$ to $138^{\circ} \mathrm{E}$ and $33^{\circ} \mathrm{S}$ to $55^{\circ} \mathrm{N}$ ) with 18 vertical levels in the atmosphere. The model is run from 00GMT of $1^{\text {st }}$ January 2009 to $24 \mathrm{GMT}$ of $31^{\text {st }}$ December 2010. For the lateral and lower boundary conditions to force the model run, NNRP 2 (NCEP-DOE AMIP-II Reanalysis (R-2)) [11] 6-hourly data

*Corresponding author: Abhishek Lodh, Indian Institute of Technology Delhi, Centre for Atmospheric Sciences, Hauz Khas, New Delhi 110016, India, Tel: 9654151118; E-mail: abhishek.lodh@gmail.com

Received October 26, 2015; Accepted November 25, 2015; Published December 03, 2015

Citation: Lodh A (2015) Impact of Caspian Sea Drying on Indian Monsoon Precipitation and Temperature as Simulated by RegCM4 Model. Hydrol Current Res 6: 217. doi:10.4172/2157-7587.1000217

Copyright: @ 2015 Lodh A. This is an open-access article distributed under the terms of the Creative Commons Attribution License, which permits unrestricted use, distribution, and reproduction in any medium, provided the original author and source are credited. 
Citation: Lodh A (2015) Impact of Caspian Sea Drying on Indian Monsoon Precipitation and Temperature as Simulated by RegCM4 Model. Hydrol Current Res 6: 217. doi:10.4172/2157-7587.1000217

Page 2 of 9

and Reynolds weekly sea surface temperature data [12] respectively, is used (Figure 1).

See Figure 1 for details of the changed land use map. Terrestrial variables like elevation, landuse, and sea-surface temperature are horizontally interpolated from a latitude-longitude world domain to a high-resolution $(90 \mathrm{~km})$ domain using Normer projection. BATS have 20 vegetation types in the model [13]. "Inland water" is the fourteenth vegetation (green color) and semi-desert is the "eleventh" vegetation (red color) in the landuse map. More details about the RegCM4.0 model and landuse map, its user guide can be found at the website: http://gforge.ictp.it/gf/project/regcm/frs/. In the design experiment the Caspian Sea is converted from "inland water" type of vegetation in the original land use map to "semi-desert". The lake model is not invoked here.

\section{Results and Discussion}

To study the impact of the drying Caspian Sea on Indian monsoons using a regional climate model, the differences in precipitation, wind magnitude and circulation at $850 \mathrm{hPa}$ and $200 \mathrm{hPa}, 2$ metreTemperature, air temperature $(850 \mathrm{hPa}$ and $700 \mathrm{hPa})$, maximum and minimum temperature, geopotential height are examined and chronologically the following findings are reported (Figure 2).
It is observed that during the January-February-March (JFM) season of 2009 and 2010 precipitation over north India, northwestern India and Pakistan decreases by- 1 to- $1.5 \mathrm{~mm} /$ day. But during MarchApril-May (MAM) season of 2009 and 2010 over Jammu and Kashmir precipitation decreases but over northwest India, northeast India precipitation increases. During the Indian summer monsoon (JuneJuly-August-September, JJAS) season precipitation over Arabian Sea decreases whereas over Bay of Bengal increases. Over Indo-Gangetic plain, parts of east India (Orissa) precipitation decreases whereas over Nepal, Central India, northwest India, northeast India and Western Ghats precipitation increases. During the October-NovemberDecember (OND) season of 2009 and 2010 precipitation over parts of North India (Jammu Kashmir, Punjab) decreases. The above results reported are significant at 5\% significance level (Figure 3).

Correspondingly during the JJAS season of 2009 it is observed that over Central India there is increase in wind magnitude, along with formation of anomalous cyclonic (anti-clockwise in northern hemisphere) circulations at $850 \mathrm{hPa}$. As a result over Central India and Western Ghats precipitation is more. But over North India there is decrease in wind magnitude. During OND season of 2009 wind magnitude is seen to be decreasing over North, Central and peninsular
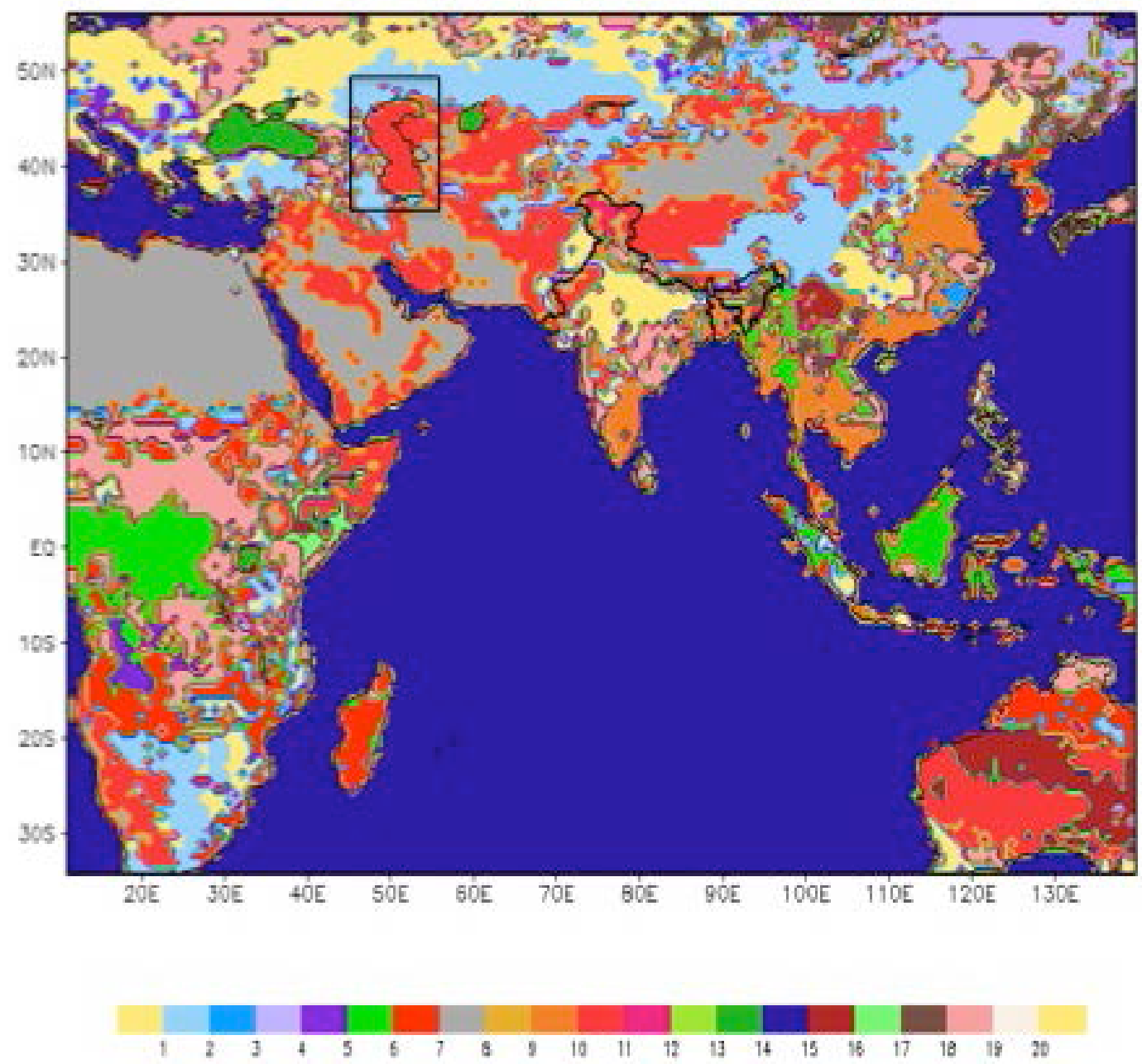

Figure 1: Designed Land use map for Caspian Sea sensitivity experiment, representing desert type of vegetation over Caspian Sea (marked and squared). 
Citation: Lodh A (2015) Impact of Caspian Sea Drying on Indian Monsoon Precipitation and Temperature as Simulated by RegCM4 Model. Hydrol Current Res 6: 217. doi:10.4172/2157-7587.1000217

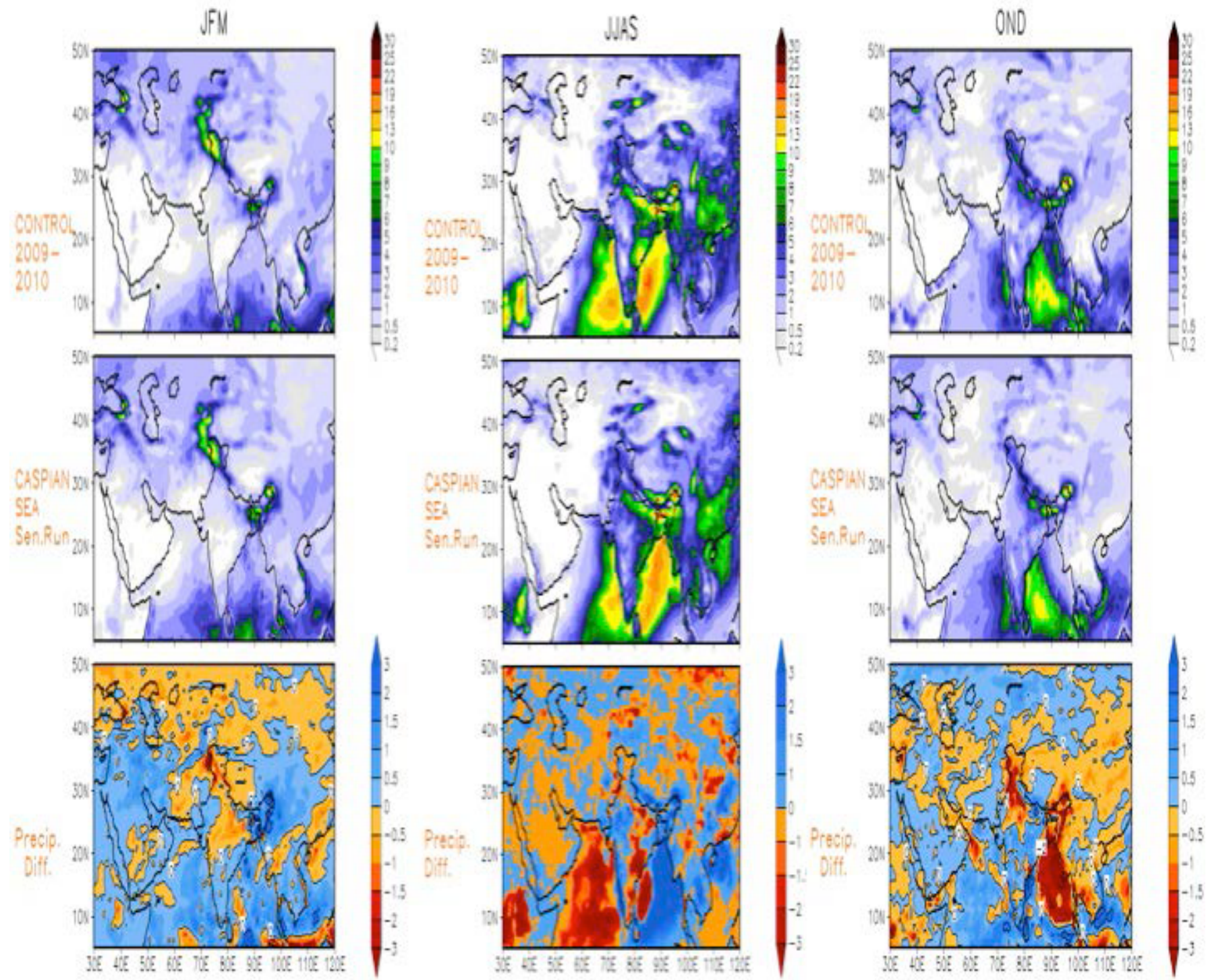

Figure 2: Design experiment precipitation change (mm/day) for (a) JFM, 2009-2010 (b) JJAS, 2009-2010 (c) OND, $2009-2010$.

India. Also during JFM 2009 season, wind magnitude is seen to be decreasing over North India. Simultaneously over North India plains, particularly over Jammu and Kashmir, and Punjab it is reported that precipitation is decreasing by- 1 to- $1.5 \mathrm{~mm} /$ day. Similar results are arsing from the analysis of precipitation and wind pattern changes for pre-monsoon, monsoon and post-monsoon season of 2010. (Figures 4 and 5)

From Figure 6, change in 2-metre temperature is observed during winter (January-February-March, JFM), monsoon (JJAS) and post-monsoon (OND) season of 2009-10. During the winter season of January-February-March the 2 metre-temperature, ground temperature; air temperature from $925 \mathrm{hPa}$ to $700 \mathrm{hPa}$ is increasing by $1-2^{\circ} \mathrm{C}$ over North India, Jammu and Kashmir, and Central Asia (Figure 7). During monsoon (JJAS) season, temperature north of $30^{\circ} \mathrm{N}$ (over Central Asia) is seen to increase whereas south of it is seen to decrease over the Indian subcontinent and China (significant at $5 \%$ level). Over Caspian Sea temperature is seen to increase in all the seasons. But during post monsoon (OND) season temperature is seen to decrease north of $30^{\circ} \mathrm{N}$ significantly. From the model output, it is observed that maximum temperature is increasing and minimum temperature is decreasing during the months, October to March and June to September. Also sea level pressure decreases north of $20^{\circ} \mathrm{N}$ and low-level geo-potential height $(850 \mathrm{hPa})$ increases over the Indian subcontinent during monsoon JJAS season (Figures 6-8).

\section{Conclusions}

Based upon the results of the study it is concluded that winter precipitation over Northern India will decrease due to drying and shrinking of Caspian Sea. The states of Punjab, Himachal Pradesh and Haryana usually get rainfall from Western disturbances during the post- monsoon and winter months starting from October to March. This is because moisture content of the westerly disturbances is augmented from the Caspian Sea, which is affected as strength of the low level winds decreases over regions north of $30^{\circ} \mathrm{N}$, during 
Citation: Lodh A (2015) Impact of Caspian Sea Drying on Indian Monsoon Precipitation and Temperature as Simulated by RegCM4 Model. Hydrol Current Res 6: 217. doi:10.4172/2157-7587.1000217

Page 4 of 9
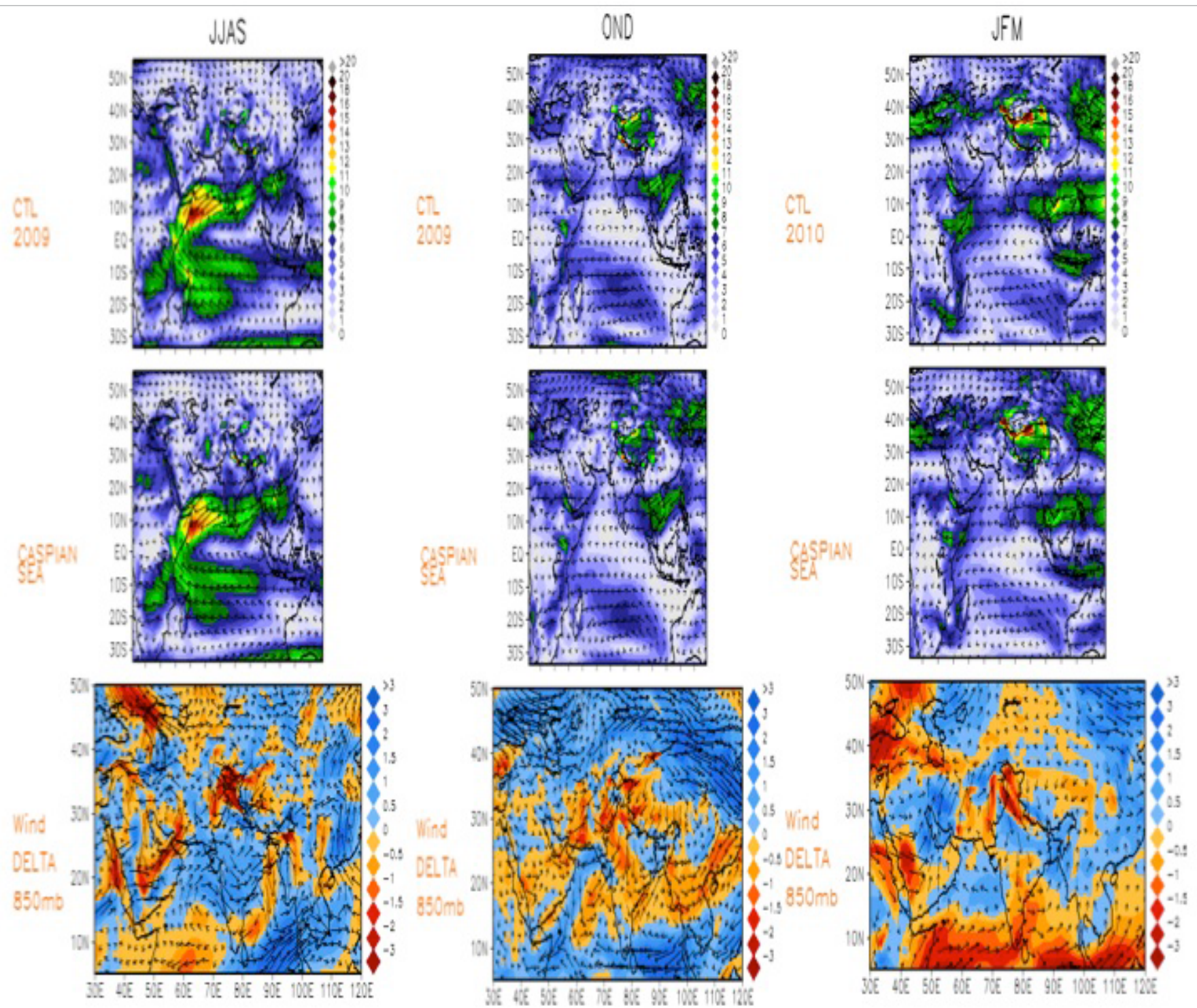

Figure 3: Design experiment anomalous wind circulations i.e. wind magnitude and circulation change (m/sec) for (a) JJAS-2009 (b) OND-2009 (c) JFM-2010.

the post-monsoon and winter months starting from October to March. It is also concluded that temperature (ground, 2metre and air temperature upto $500 \mathrm{hPa}$ ) over Central Asia, Pakistan and northern regions of India will increase by $1-2^{\circ} \mathrm{C}$, strengthened by previous climate model results as reported by Lioubimtsevaa et al. 2005) [1]. Decrease in ground temperature over Central India during monsoon (JJAS) season, increase in geopotential height coupled with dry air intrusions from Central Asia will impact the Indian summer monsoon. Hence, progress of Indian summer monsoon will be delayed as summer heating of Indian land mass is also delayed [3]. As it is observed from the sensitivity experiment results that maximum temperature is increasing and minimum temperature is decreasing, which mean days are getting hotter and nights are getting colder. For better understanding of the relationship between climate, ecosystem and hydrosphere, further modelling studies is required along with remote sensing studies. The experiments in future will be done for more number of years for better understanding.

\section{Acknowledgment}

The author is grateful to Institute student fellowship (GATE) provided by MHRD (Govt. of India). Also acknowledged the central cloud-computing facility available at Computer Services Centre, IIT Delhi for the regional climate model simulations. The author is equally thankful to ICTP, International Centre for Theoretical Physics, Trieste, Italy for making available the regional climate model codes of RegCM4.0 freely available for this research study and NCEP/NCAR for providing highresolution meteorological datasets for setting the initial and boundary conditions to run the model. The Grid Analysis and Display System (GrADS) version 2.0 software is used for plotting. The author acknowledges Dr. H.C. Upadhyaya for his helpful suggestions to improve the write-up of the study and for permitting the submission of the paper to this journal. The author also acknowledges the research work done by researchers previously in the field of climate change, climate modelling and associated studies. Wealth of online resource available at www.google.com, scholar.google.com was also helpful.

\section{References}

1. Lioubimtsevaa E, Cole R, Adamsb JM, Kapustinc G (2005) Impacts of climate and land-cover changes in arid lands of Central Asia.Journal of Arid Environments 62: 285-308.

2. Chaudhari HS, Shinde MA, Oh JH (2008) Understanding of anomalous Indian 
Citation: Lodh A (2015) Impact of Caspian Sea Drying on Indian Monsoon Precipitation and Temperature as Simulated by RegCM4 Model. Hydrol Current Res 6: 217. doi:10.4172/2157-7587.1000217

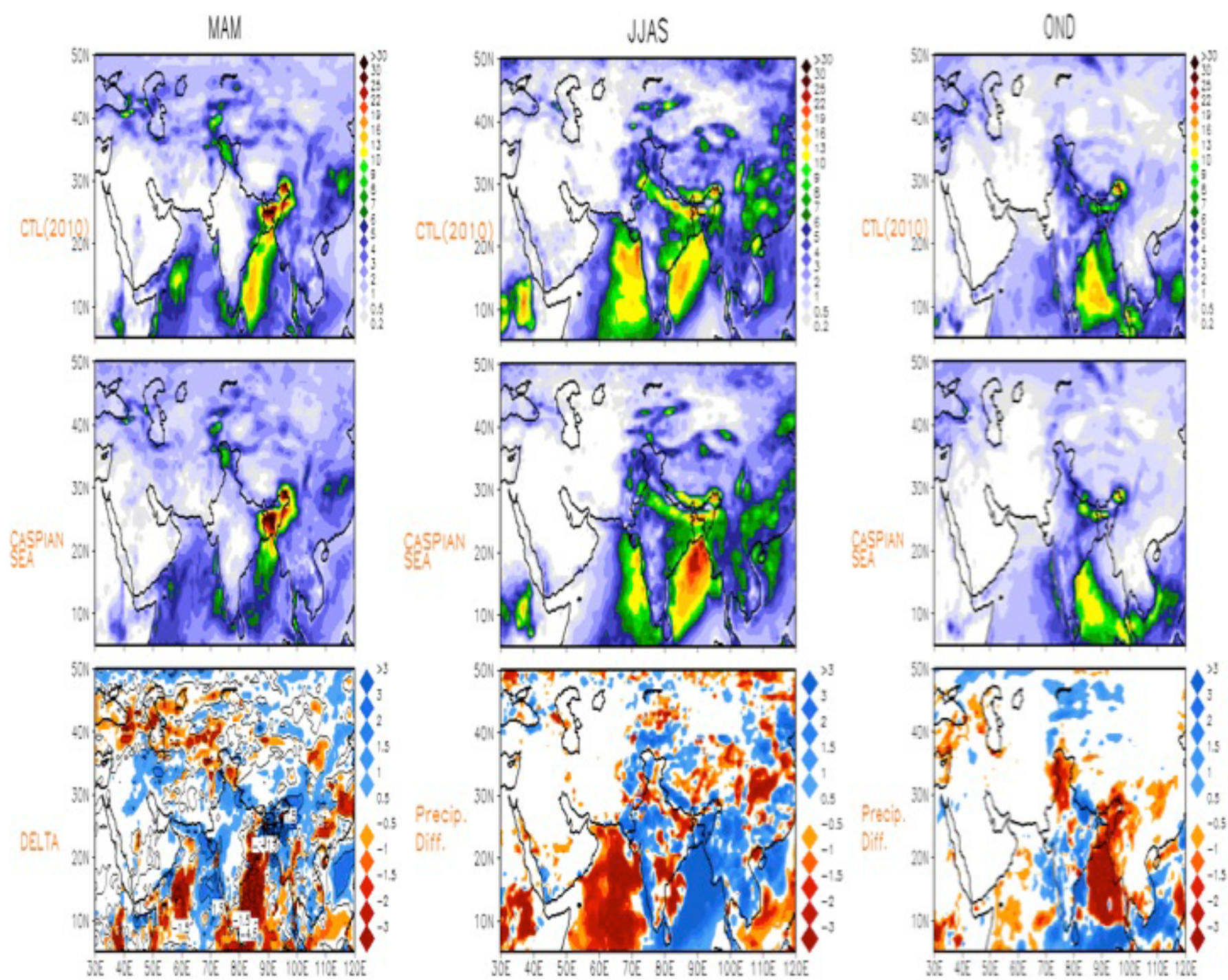

Figure 4: Design experiment precipitation change (mm/day) for (a) MAM, 2010 (b) JJAS, 2010 (c) OND, 2010.

Summer Monsoon rainfall of 2002 and Quaternary International, doi:10.1016/j. quaint.2008.05.009.

3. Rajeevan M (1993) Upper tropospheric circulation and thermal anomalies over central Asia associated with major droughts and floods in India, Research Communications 64: 244-247.

4. Krishnamurthi TN, Bedi HS, Subramaniom M (1989) The Summer Monsoon of 1987.Journal of Climatology 2: 321-340.

5. Giorgi F (2012) RegCM4: model description and preliminary tests over multiple CORDEX domains. Climate Research 52: 7-29.

6. Elguindi Nellie, Xunqiang Bi, Filippo Giorgi, Badrinath Nagarajan, Jeremy Pal, et al. (2010) RegCM Version 4.0 Core Description, The RegCM Team Trieste.

7. Lodh A, Jha S, Raghava R (2011) Impact of El Niño and La Niña on soil moisture - precipitation feedback of Indian monsoon over Central India. Int. Arch. Photogrammetry. Remote Sens 102-108.

8. Lodh Abhishek, Ramesh Raghava (2013) Soil moisture-precipitation feedback on Indian climatic zones in Indian summer monsoon regime, Vayumandal 38: 46-55.

9. Lodh A, Raghava R, Singh K and Kumar S (2014) Climatology of Atmospheric Flow and Land Surface Fields of Indian Monsoon Captured in High Resolution Global and Regional Climate Model, Earth Science and Climate Change S11.

10. Lodh A (2015) Studying Himalayan snow-Indian monsoon relationship by some LULCC change sensitivity experiments in RegCM4.0, International Journal of Geology and Earth Sciences.

11. Kanamitsu W, Ebisuzaki JW, Yang SK, Hnilo JJ, M. Fiorino, et al. (2002) NCEPDEO AMIP-II Reanalysis (R-2) 21631-1643, Bulletin of the Atmos. Met. Soc.

12. Reynolds RW, Rayner NA, Smith TM, Stokes DC, Wang W (2002) An improved in situ and satellite SST analysis for climate. J Climate 15: 1609-1625

13. Dickinson RE, Henderson-Sellers A, Kennedy PJ (1993) Biosphere-atmosphere transfer scheme (bats) version $1 \mathrm{e}$ as coupled to the NCAR community climate model, Tech. rep., National Center for Atmospheric Research. 
Citation: Lodh A (2015) Impact of Caspian Sea Drying on Indian Monsoon Precipitation and Temperature as Simulated by RegCM4 Model. Hydrol Current Res 6: 217. doi:10.4172/2157-7587.1000217
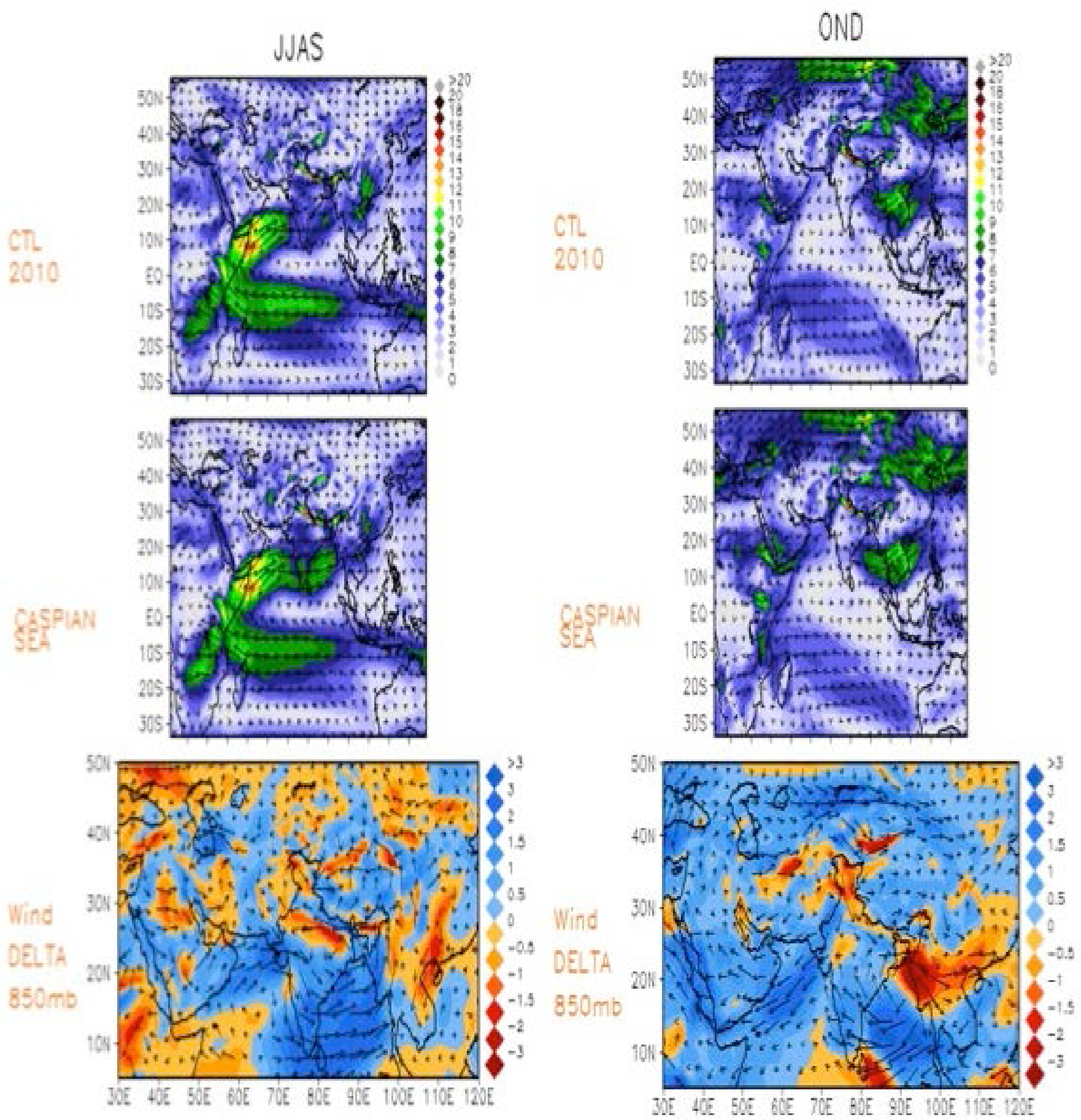

Figure 5: Design experiment anomalous wind circulations i.e. wind magnitude and circulation change (m/sec) for (a) JJAS, 2010 (b) OND, 2010. 
Citation: Lodh A (2015) Impact of Caspian Sea Drying on Indian Monsoon Precipitation and Temperature as Simulated by RegCM4 Model. Hydrol Current Res 6: 217. doi:10.4172/2157-7587.1000217

Page 7 of 9

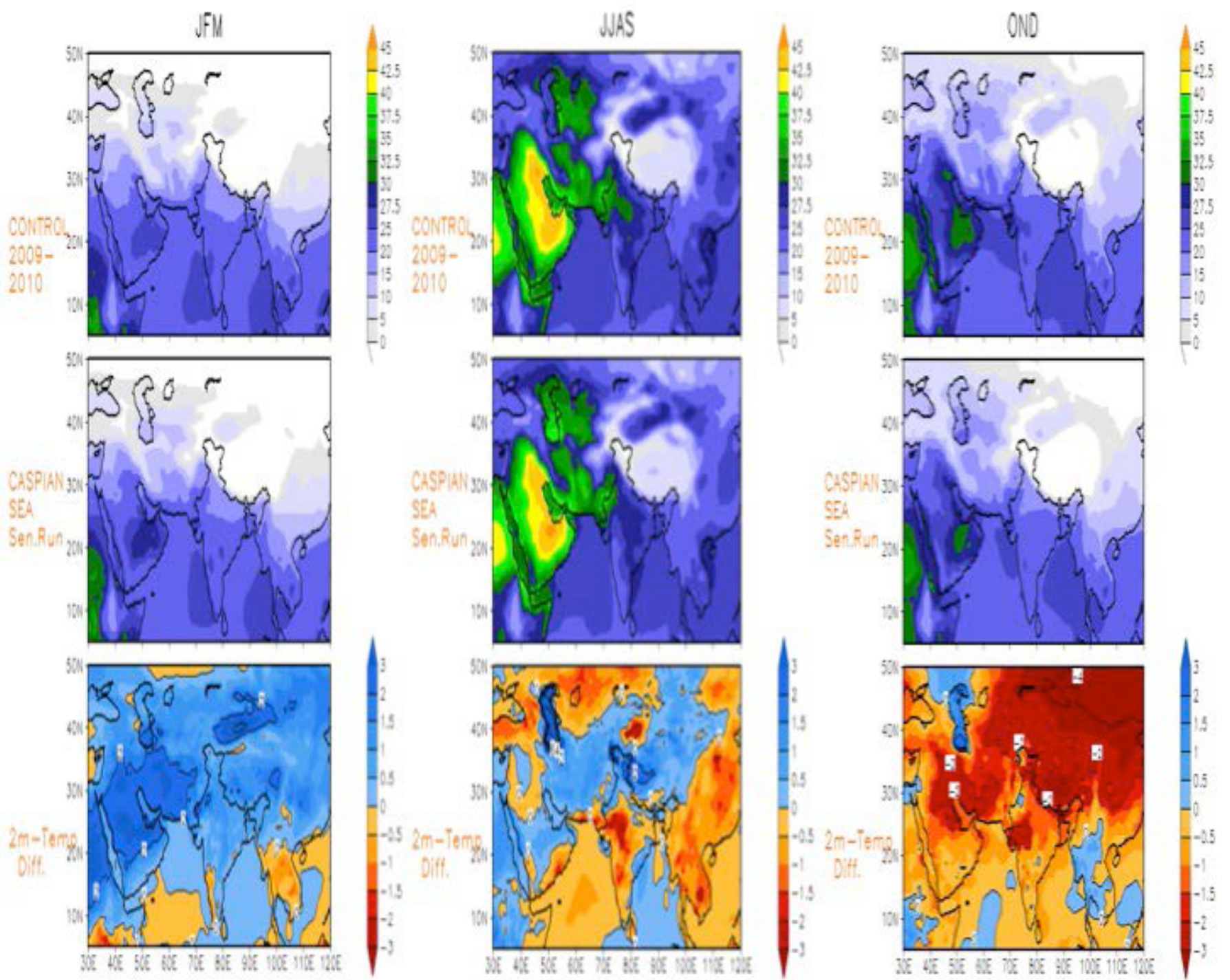

Figure 6: Design experiment 2metre-Temperature change $\left({ }^{\circ} \mathrm{C}\right)$ for (a) JFM, 2009-2010 (b) JJAS, 2009-2010 (c) OND, $2009-2010$. 
Citation: Lodh A (2015) Impact of Caspian Sea Drying on Indian Monsoon Precipitation and Temperature as Simulated by RegCM4 Model. Hydrol Current Res 6: 217. doi:10.4172/2157-7587.1000217

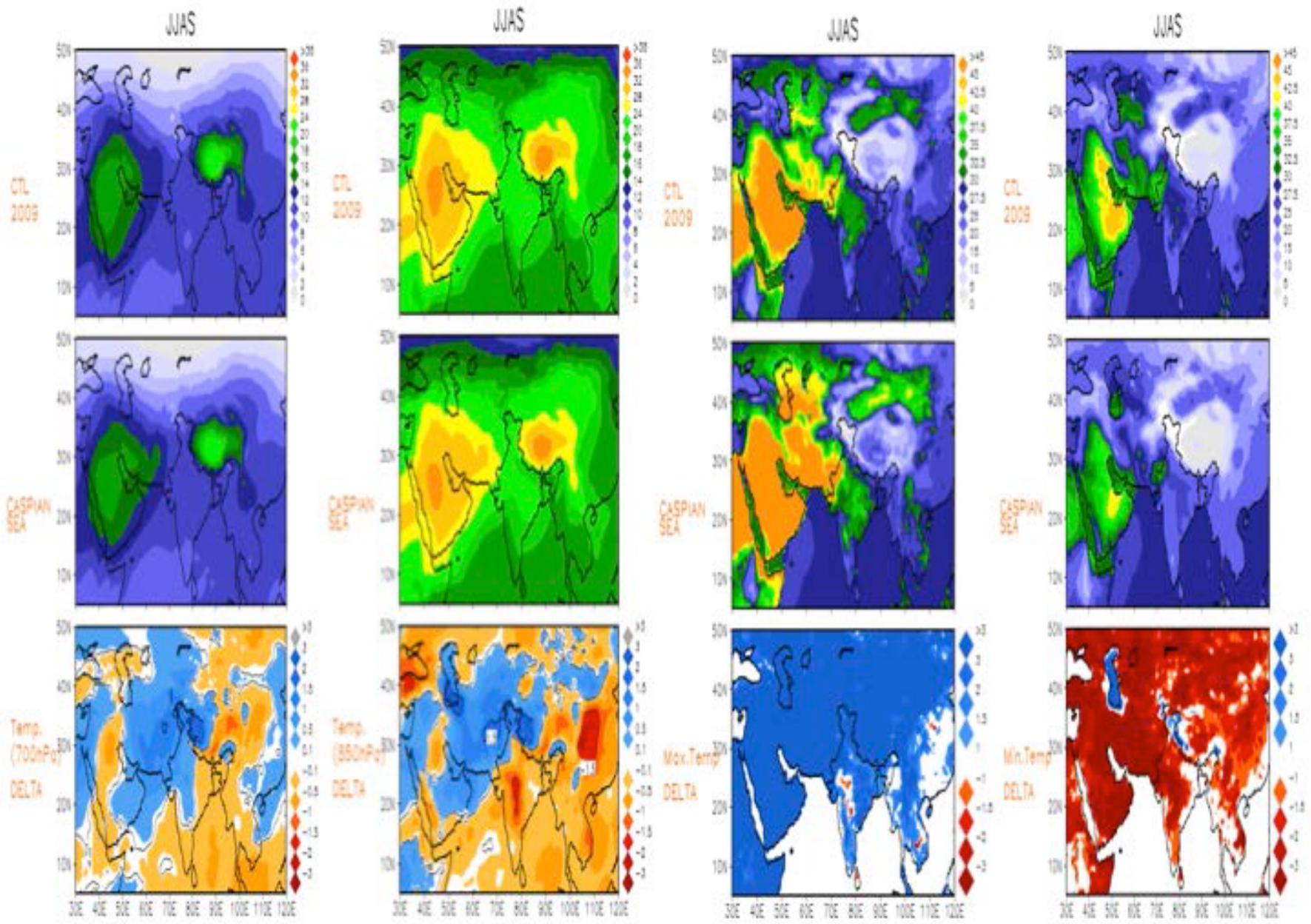

Figure 7: Design experiment air temperature change $\left({ }^{\circ} \mathrm{C}\right)$ for JJAS, 2009 at (a) $700 \mathrm{hPa}(\mathrm{b}) 850 \mathrm{hPa}$, and (c) maximum and (d) minimum temperature change 
Citation: Lodh A (2015) Impact of Caspian Sea Drying on Indian Monsoon Precipitation and Temperature as Simulated by RegCM4 Model. Hydrol Current Res 6: 217. doi:10.4172/2157-7587.1000217
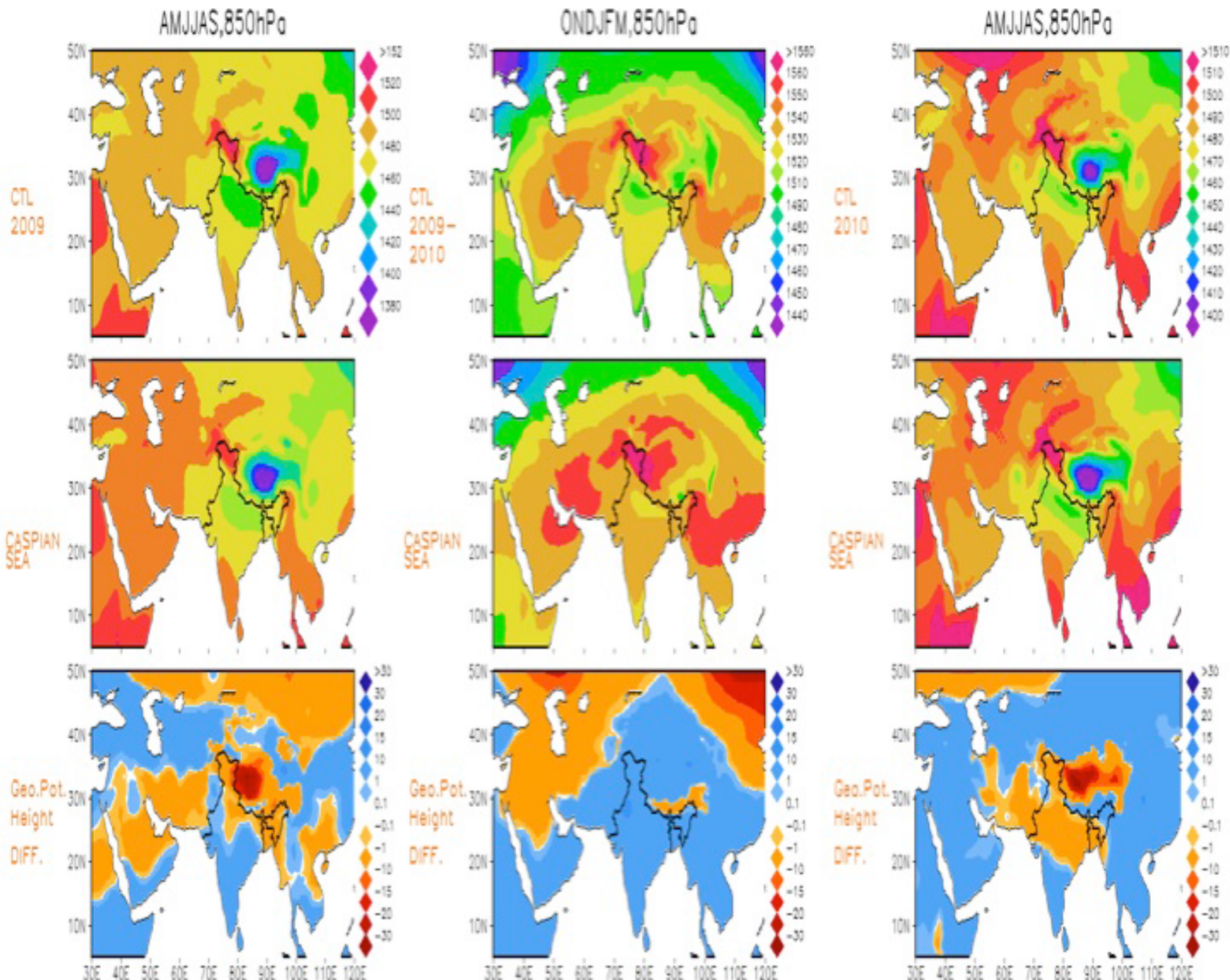

Figure 8: Design experiment Geopotential height change (m) at 850hPa for (a) AMJJAS, 2009 (b) ONDJFM, $2009-2010$ (c) AMJJAS, 2010. (Here AMJJAS stands for April-May-June-July-August-September, and ONDJFM stands for October-November-December-January-February-March of 2009-2010) 